\title{
Spatio-Temporal Assessment of Vegetation Resource Dynamics in Nigeria from SPOT Satellite Imageries
}

\author{
Sadiq Abdullahi Yelwa1* ${ }^{*}$, Aliyu Bilya Sanda1, Umar Usman² \\ ${ }^{1}$ Department of Environmental and Resources Management, Faculty of Engineering and Environmental Design, Usmanu \\ Danfodiyo University, Sokoto, Nigeria \\ ${ }^{2}$ Department of Mathematics and Statistics, Faculty of Science, Usmanu Danfodiyo University, Sokoto, Nigeria \\ Email: *sadiq.abdullahi@udusok.edu.ng
}

How to cite this paper: Yelwa, S.A., Sanda, A.B. and Usman, U. (2019) Spatio-Temporal Assessment of Vegetation Resource Dynamics in Nigeria from SPOT Satellite Imageries. American Journal of Climate Change, 8, 502-519.

https://doi.org/10.4236/ajcc.2019.84027

Received: July 30, 2019

Accepted: November 29, 2019

Published: December 2, 2019

Copyright $\odot 2019$ by author(s) and Scientific Research Publishing Inc. This work is licensed under the Creative Commons Attribution International License (CC BY 4.0).

http://creativecommons.org/licenses/by/4.0/

\begin{abstract}
Vegetation resources in Nigeria are of vital importance for the sustainable development of the country. However, this essential resource is in danger due to the effect of anthropogenic and climate induced impacts. Currently desert encroachment which cuts across the Sahel is affecting most of the states in the northern part of the country particularly the eleven states considered by the Federal Ministry of Environment in Nigeria as the frontline states. Several studies on the Nigerian environment have shown that there are serious threats to the general environment particularly vegetation. Due to population growth and the need for housing as well as the expansion of the over-utilised farmlands across these states, places considered as reserved areas across the country are being exploited to the detriment of the vegetal resources particularly the forest and rangeland areas. This study utilized Idrisi TerrSet (version 18) raster-based remote sensing and GIS software to analyse seventy two (72) dekadal Normalised Vegetation Index (NDVI) imageries from SPOT satellite covering Nigeria in order to assess the anthropogenic and likely climatic impacts on the vegetal resources using the forward t-mode Principal Component Analysis (PCA) with standardised principal components. Results indicated that Component 1 which explains about $69 \%$ of the 72 time-series NDVI imageries shows typical vegetation cover over the study area within the time period under study. While component two indicated a cyclic trend differentiating the ENSO events of 1999 and 2009; component three indicated positive anomaly pattern of vegetation NDVI mostly within Sokoto, Kebbi, Kano, Jigawa and the northern parts of Bauchi, Yobe and Borno states. However, Component four imagery indicated a likely link to the 2009 flood that affected Kainji dam and rivers Niger and Benue. For a better result, the inte-
\end{abstract}


gration of socio-economic and high spatial resolution data into an assessment of this kind in future studies is encouraged.

\section{Keywords}

Vegetation, Resources, Desertification, NDVI, SPC

\section{Introduction}

One of the vital resources across Nigeria being threatened by a combination of natural and man-made impacts is vegetation. Accordingly, the issue of desert encroachment particularly across the northern parts of the country referred to as the frontline states namely: Adamawa, Bauchi, Borno, Gombe, Jigawa, Kano, Katsina, Kebbi, Sokoto, Yobe and Zamfara states is a very serious issue of concern (Figure 1(b)). Desertification in Nigeria is caused by land degradation in the northern states where poor land management and environmental pressure is on the increase [1] [2]. In the southern part of the country this is caused by mismanagement of the environment due to activities related to exploration of petroleum resources. All these affect the vegetation status across the country.

Vegetation influences the energy balance at the earth's surface and in the atmospheric boundary layer, often mitigating extremes of local climate [3]. The vegetation cover of Nigeria reflects past and present climatic variations and its current status particularly forest areas, had an annual deforestation rate of $5 \%$ per annum of its closed forests [4]. This can be considered as one of the highest in the world. Hence, rapid population growth and demands for economic development on a relatively natural, and in some areas, undisturbed vegetation which is not properly managed can also lead to permanent conversion of most vegetated areas to other forms of land use such as agriculture and housing in Nigeria. Studies dealing with vegetation dynamics can be undertaken using different remote sensing and GIS techniques. For example, [5] utilised remotely sensed data for assessing vegetation resources of Nigeria. Other studies which utilised NDVI from satellite data [6]-[11] have shown that NDVI data can provide an effective measure of photosynthetically active biomass. Other environmental studies relating to vegetation dynamics covering whole or part of Nigeria using satellite data include [12]-[18]. On the other hand, vegetation provides habitat to wildlife and ecosystem services such as food and fuel, timber, cash crops, pulp, fruits, robes, clothes and many game reserves [19]. Furthermore, the use of Principal Component Analysis (PCA) employing the standardised principal components (SPC) in environmental studies including vegetations resource dynamics using remotely sensed data analysed in a geographical information systems (GIS) environment indicated clearly that the major element of variability is that which occurs spatially [20] [21] [22]. However, the earlier studies on Nigeria did not utilise PCA with standardised principal components (SPC), hence the choice of this methodology using SPC. Principal Component Analysis using SPC 


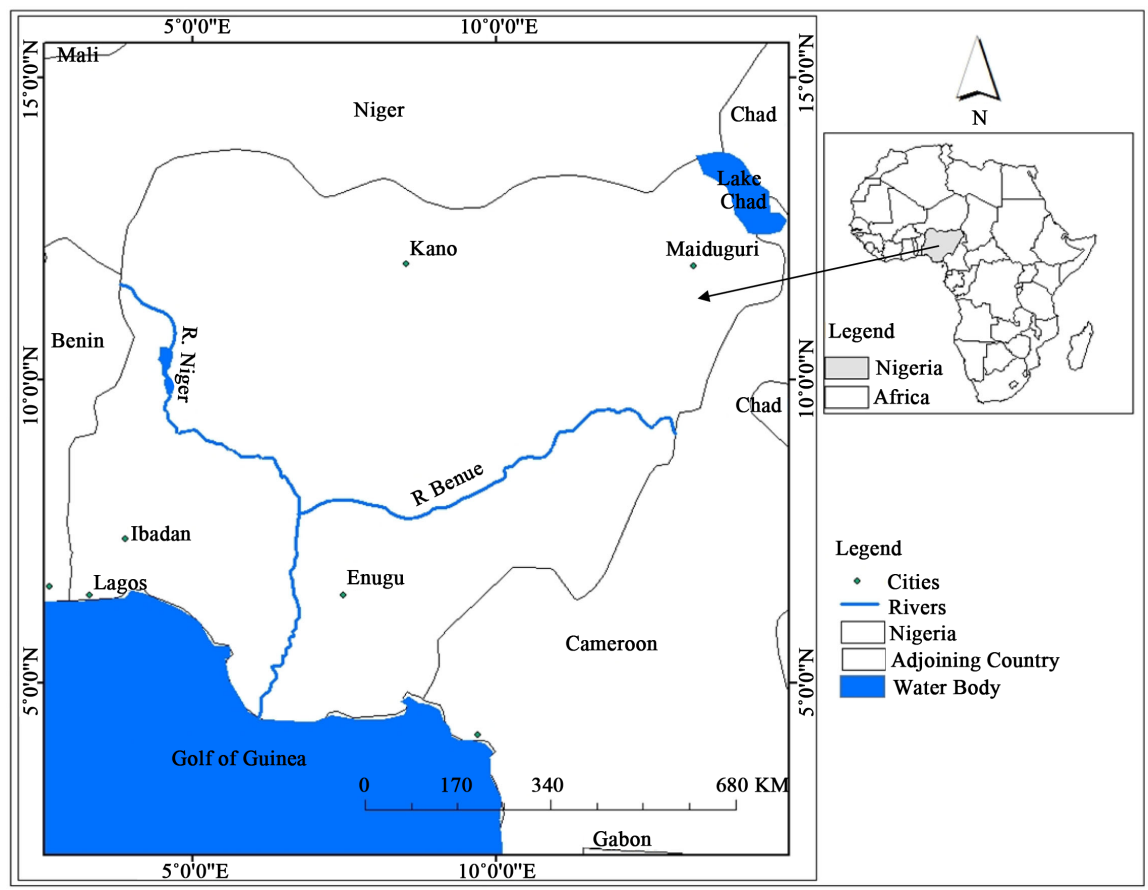

(a)

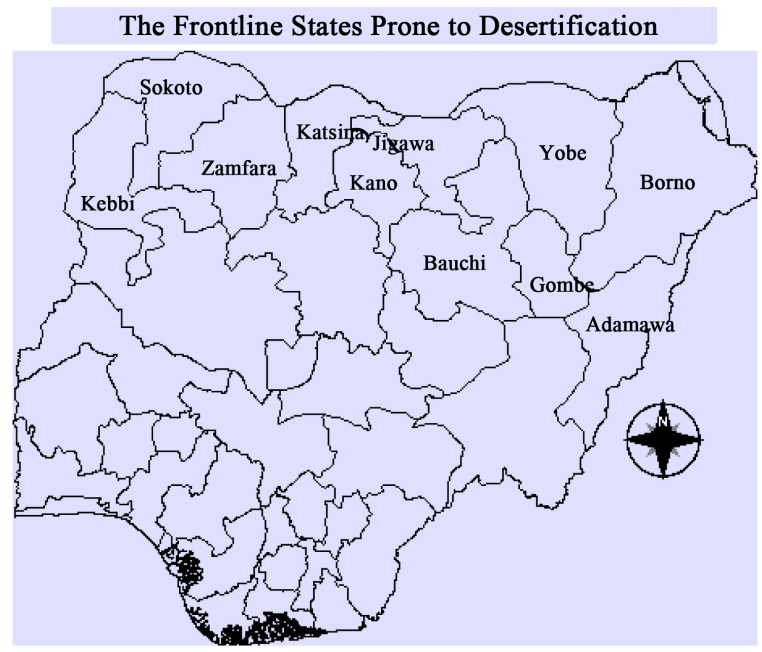

(b)

Figure 1. Location of the study area and areas prone to desertification. (a) The study area covered by the SPOT Satellite data; (b) The frontline states of Nigeria (areas prone to desertification).

allows any set of original satellite imageries or data to be transformed to a set of new images (referred to as components). Such component images in most cases contain all of the information in the original images entered into such time-series and, are uncorrelated with one another [23] [24]. The interpretation of the extracted component images thus, relies on a combination of spatial and temporal analysis. According to the United Nations [25], about 5 million hectares of degraded land across these states have been restored based on the review and progress report by Nigeria on the implementation of the Agenda 21 of the 
United Nations [26]. The purpose of this broad vegetation dynamic assessment therefore, is to verify this assertion and to present a cost effective approach where seventy two (72) remotely sense data derived from SPOT satellite in the form of dekadal Normalised Difference Vegetation Index (NDVI) (Table 1) were analyzed within a GIS environment in order to highlight areas or serious concern with regards to changes in vegetation across Nigeria. In particular, more emphasis will be on the front-line states during the El-Nino and La-Nina (ENSO) periods of 1999 and 2009 respectively. When these areas of serious concern are identified either due to the impact of the ENSO or other anthropogenic factors, they can be targeted with systematic monitoring using a very high spatial resolution satellite imageries for sustainable vegetation resources management across the country.

\section{Location and Geographical Setting}

The study area covers mainly Nigeria but includes southern part of Niger Republic, as well as parts of Cameroon and Republic of Benin. The whole area is bounded within Latitude $4.15^{\circ}$ to $14.1^{\circ} \mathrm{N}$ and Longitude $02.6^{\circ}$ to $14.71^{\circ} \mathrm{E}$. The Area covers 1115 row by 1355 columns of ( $1 \mathrm{~km}$ spatial resolution) SPOT Satellite Imageries (Figure 1(a)). As far as Nigeria is concerned, it falls within a humid tropical climate type because of its location just north of the equator. The country experiences a tropical climate characterised by the hot and wet conditions associated with the movement of the Inter-Tropical Convergence Zone (ITCZ) north and south of the equator.

The climatic condition of the northern part of Nigeria exhibits only two distinct seasons, namely, short wet and a prolonged dry season. The seasonal pattern of climatic conditions over Nigeria gives rise to four seasons in the south and two in the north. This is the result of annual total rainfall occurrence and distribution, which is more predominant in the south than in the north. The mean annual rainfall along the coast in the south-east is about $4000 \mathrm{~mm}$ while it is slightly above $500 \mathrm{~mm}$ around Kano in the north, particularly during the El-Nińo phase of 2009 (Figure 2(b)). However, the monthly rainfall during the La-Nińa phase of 1999 was above $600 \mathrm{~mm}$ in one of these front-line states of Kebbi in Yelwa (Figure 2(a)). According to [27] however, the annual rainfall in the northern part of Nigeria study area (southern part of the Niger Republic and the extreme northern part of Nigeria) falling in the savanna vegetation zone of

Table 1. Percentage variance of component images.

\begin{tabular}{cc}
\hline Component Image & Percentage Variance (\%) \\
\hline Comp 1 & 68.704009 \\
Comp 2 & 12.831273 \\
Comp 3 & 2.966274 \\
Comp 4 & 1.567025 \\
\hline
\end{tabular}

Source: PCA Analysis. 


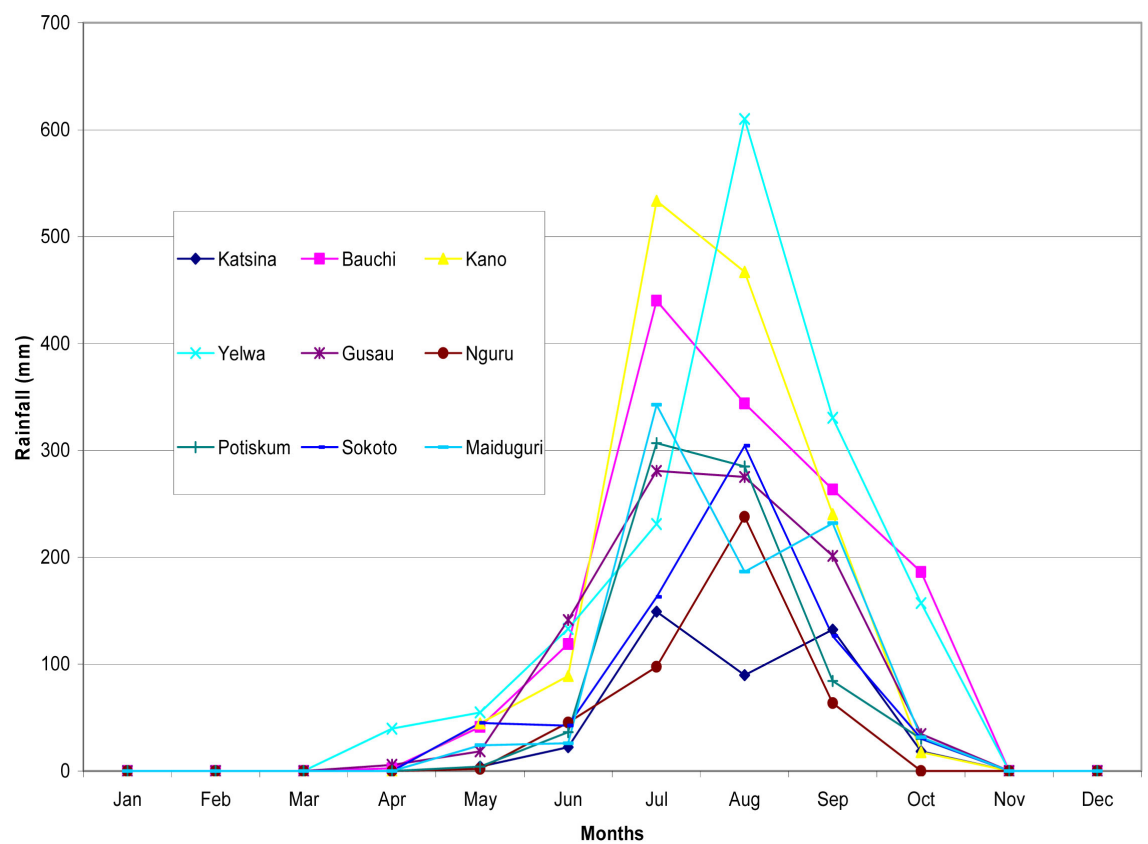

(a)

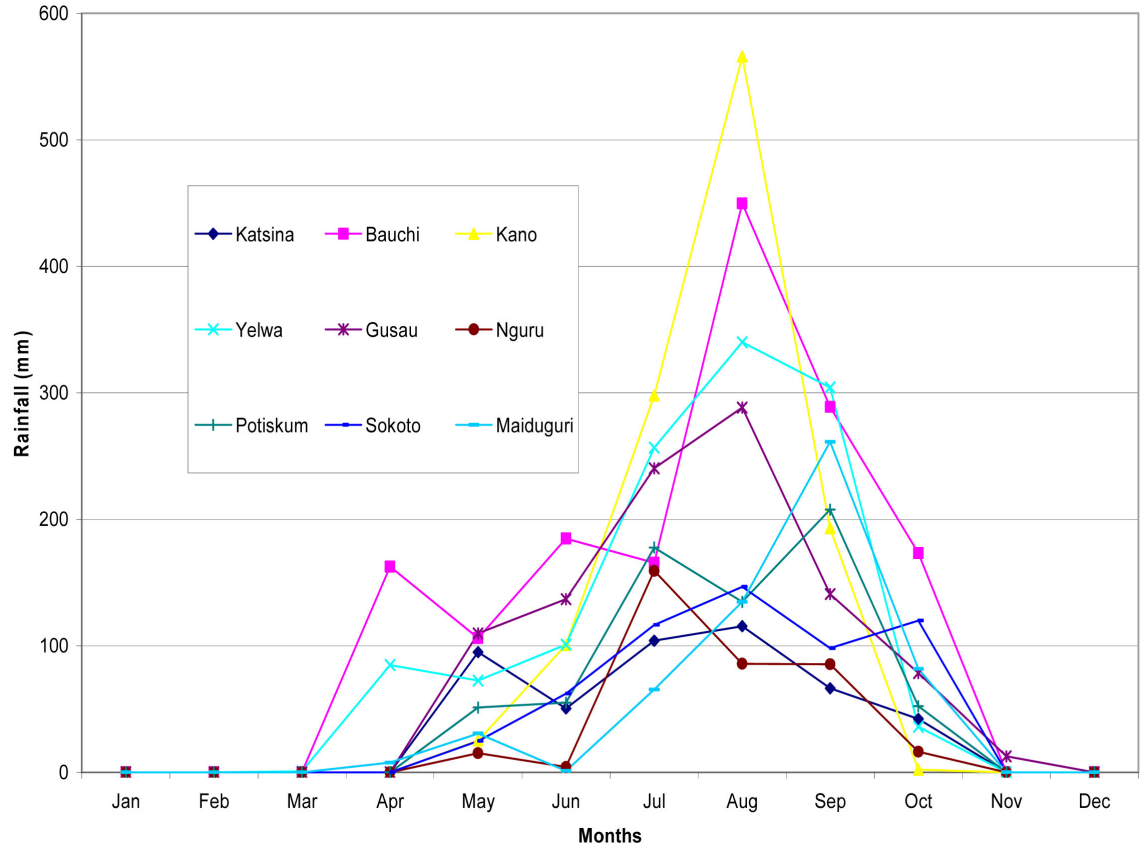

(b)

Figure 2. Rainfall from stations within the northern front line states during the ENSO. (a) The 1999 La-Nina phase (source: data analysis); (b) The 2009 El-Nino phase (source: data analysis).

the country is not only $(50-100 \mathrm{~mm})$ than in the rainforest and other parts of the southern forested areas of Nigeria, (i.e. the Niger Delta, Cameroon, southern part of Republic of Benin) but the distribution throughout the year is less even. The rainy season also varies, as it ranges from eight to ten months in the southern forest zones (towards the southern part of the study area) to less than four 
months in the extreme northern savanna (towards the Sahel on the Nigeria-Niger border). This rainfall variation from the northern to the southern part can be attributed to the fluctuation of ITCZ [28] [29]. The relationships between soil types and vegetation as well as between soil and the local topography can also be noticed for example, in areas of smooth relief. For example, in some parts of the north-west of the country around Kebbi state or in some parts of the north-east (around Maiduguri in Borno State) there are areas of smooth relief compared to areas around Adamawa state where the elevation is high, and the upper slopes mostly contain inactive soil, rather than the clayish type that can be seen in the immediate surroundings [30]. Furthermore, the soils on the lower slopes are formed by the washing down of material and are likely to be more stony and sandy, and hence, the vegetation around these 11 frontline states (Figure $1(b)$ ) is very scantly and susceptible to erosion.

\section{Materials and Methods}

Imageries in the form of normalized difference vegetation index (NDVI) were acquired from the SPOT VEGETATION satellite managed by the European Space Agency (ESA) and the Belgium Development Agency (BELSPO). The dataset (imageries) in zipped format was extracted through VGTExtract program that allowed users to extract certain Regions Of Interest (ROIs) from the Vegetation (VGT) products accessed from the data gateway www.spot-vegetation.com website. After the dataset for the Africa continent was downloaded, it was imported into the Idrisi TerrSet (Version 18) raster-based remote sensing and GIS software where the geographical coordinates corresponding to the study area centered on Nigeria was windowed (extracted) from the African continental normalized difference vegetation index (NDVI) dataset. A total of seventy two (72) dekadal NDVI dataset (imageries) covering Nigeria and few areas from adjoining countries for the 1999 and 2009 El-Nino Southern Oscillations (ENSO) years (in dekadal images from Jan 1-10 through to Dec 1-31) were used as input and analysed within a Geographical Information Systems environment. The procedure utilised the forward t-mode Principal Component Analysis (PCA) with standardised principal components (SPC). From the PCA analysis 72 component images were derived (36 for each of the ENSO years) including component loadings and eigenvectors which correspond to each of the component images as output. A sample of these four (4) components (totaling about $86 \%$ of the variance) indicates their respective percentage correlation with the total dataset used as input in the analysis (Table 1). The PCA procedure clearly indicated broadly areas where changes in vegetation status across Nigeria occurred covering the 1999 strong La-Nina and 2009 moderate El-Nino years. Rainfall data from the Nigerian Meteorological Agency (NiMeT) covering the 1999 and 2009 ENSO years were plotted and compared. Component 1 Images of the two ENSO years (1999 and 2009) were subjected to simple image differencing and classification so as to highlight areas across the study area where negative and positive changes in vegetation occurred (Table 2). It should be noted that higher values 
Table 2. Changes in vegetation cover and classes 1999-2009 (Hectares).

\begin{tabular}{cccccc}
\hline Category & $\begin{array}{c}\text { Vegetation } \\
\text { Classes }\end{array}$ & $\begin{array}{c}1999 \\
\text { (Hectares) }\end{array}$ & $\begin{array}{c}\text { 2009 } \\
\text { (Hectares) }\end{array}$ & $\begin{array}{c}\text { Changes from } \\
\mathbf{1 9 9 9} \text { to 2009 }\end{array}$ & $\begin{array}{c}\text { (\%) of Change } \\
(\mathbf{1 9 9 9 - 2 0 0 9 )}\end{array}$ \\
\hline $\mathbf{1}$ & Water Bodies and Low Vegetation & $117,661,704$ & $117,461,974$ & $-199,730.0299$ & -0.17003803 \\
$\mathbf{2}$ & Low Vegetation Areas & $26,707,968.7$ & $25,711,081.7$ & $-996,886.9365$ & -3.87726564 \\
$\mathbf{3}$ & Irrigated or Moderate Vegetation & $2,248,887.42$ & $3,448,528.87$ & $1,199,641.444$ & 34.7870495 \\
$\mathbf{4}$ & Natural Vegetation & $30,585.0255$ & $27,560.5484$ & -3024.477122 & -10.9739366 \\
\hline
\end{tabular}

(Source: Simple Image differencing analysis)

of NDVI on the satellite data (imagery) indicate greater vigor and amounts of vegetation and low values indicate sparse vegetation or bare land, while water bodies are negative or very close to zero [31].

\section{Results and Discussion}

This broad analysis of vegetation dynamics with PCA utilized the forward $\mathrm{t}$-mode process where each image band was analyzed as a (temporal) variable which resulted into new set of principal component images that are uncorrelated with each other and explain progressively less of the variance found in the original set of NDVI imageries. A table of the component loadings and eigenvectors were also derived as part of the output. For t-mode forward PCA, using standardized variables utilized here, was meant for data compression or noise removal which essentially gives equal weight to all the bands and, it is often the case that the first four components typically explain close to or slightly 90 percent of the total variance in the original data set. Those components explaining less than a certain percent of the variance can be dropped and the inverse procedure used to reconstruct a new data set. Although results for this assessment yielded 72 components and their corresponding loading scores, the discussion is limited to only four component images and their corresponding loading scores as they represent $86 \%$ of the total variances from the original NDVI images utilized in the analysis, thereby indicating changes of varying degrees across Nigeria.

\subsection{Component 1 Image and Its Loading Scores}

Component I image (Figure 3(a)) explains about $69 \%$ of the total variance of the 72 time-series NDVI dataset utilized in this assessment. This illustrates a typical vegetation pattern across Nigeria and the neighbouring countries covering the 10-year period between 1999 and 2009. The image thus, shows areas that are less correlated with the dataset located mostly in the northern savanna vegetation covering the 11 front-line states impacted by desert encroachment appearing yellow and brownish in colour indicate either bare land or very less vegetation vigor. On the other hand, areas that are highly correlated with the dataset are located in the southern forest zone of the country, the irrigated area around Lake Chad and part of southern Cameroun. These are all in green colour signifying more vegetation vigor. The corresponding graph of the loading scores (Figure 4(b)) shows correlations between the component image and the whole 72 


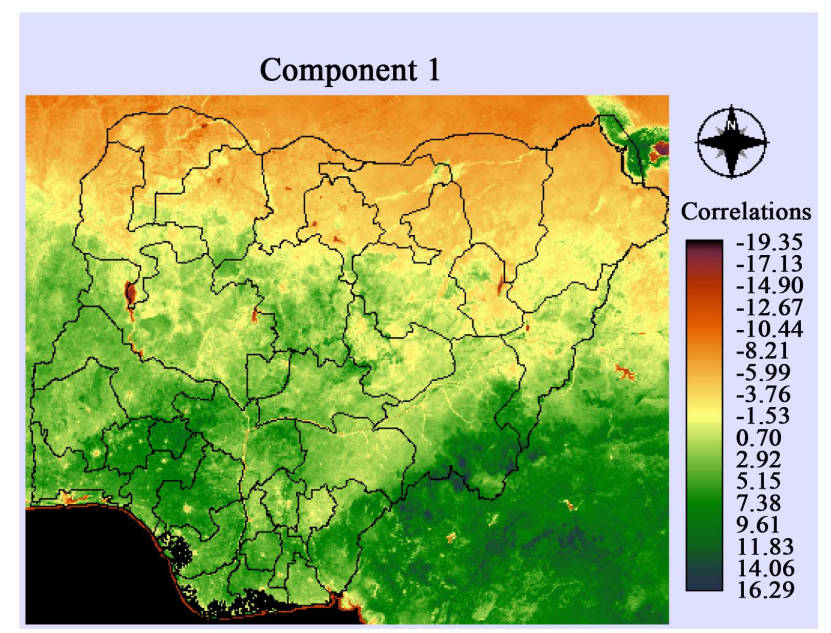

(a)

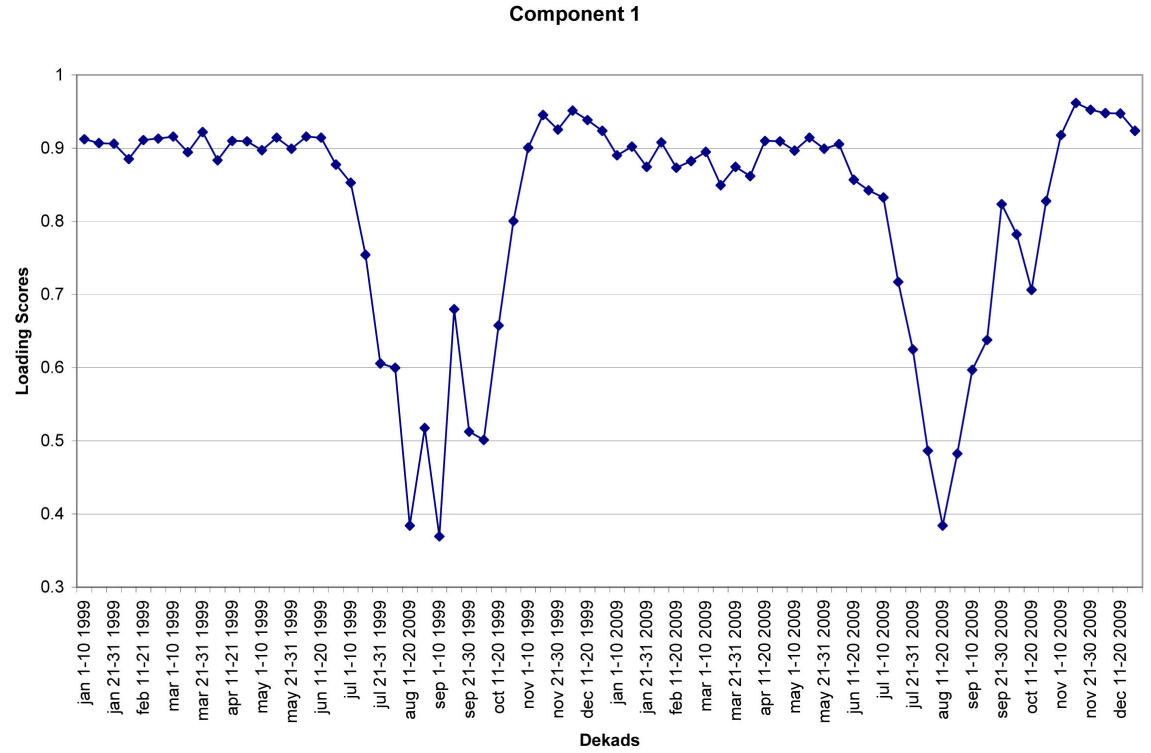

(b)

Figure 3. Component 1 image and its graph of loading scores (source: PCA analysis). (a) Component 1 Image; (b) Graph of Component 1 loading scores.

time-series NDVI dataset as positive figures. A further look at this graph shows low peaks for the second dekad in August and first dekads in both September and October 1999. This is likely to correspond to the impact of the moderate La-Nina of 1999 which affected some parts of the country especially in the Savanna vegetation zone. Another corresponding low peaks can be seen in the second dekads in August and October 2009 respectively, which correspond to the strong El-Nino event of 2009. What is worth observing also on this component image is the brownish pattern along the coastal areas particularly in the Niger delta and major dam sites. For example, during this ten-year period the country had experienced environmental degradation based on the activities of the oil exploration companies like Shell and Chevron as well vandalisation of oil pipelines and the recession of the coastal waters and drying of major lakes. Most 


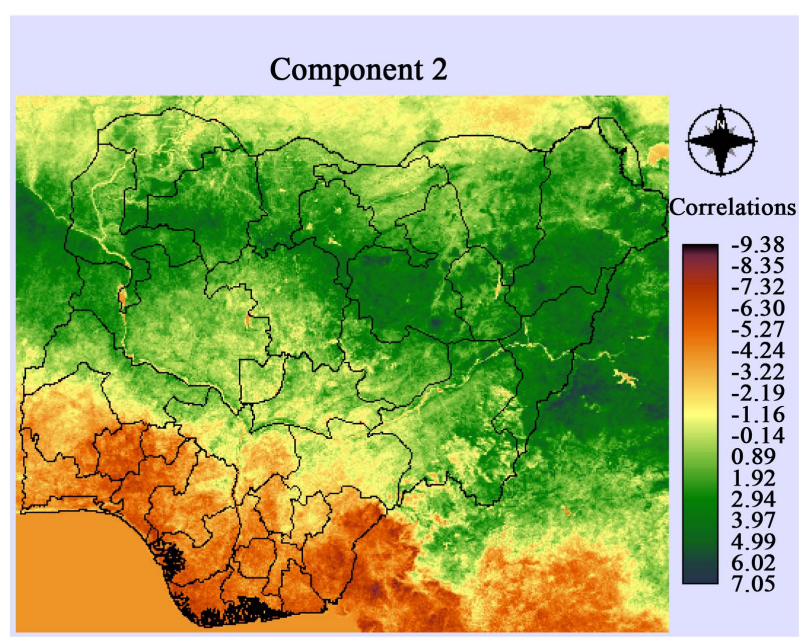

(a)

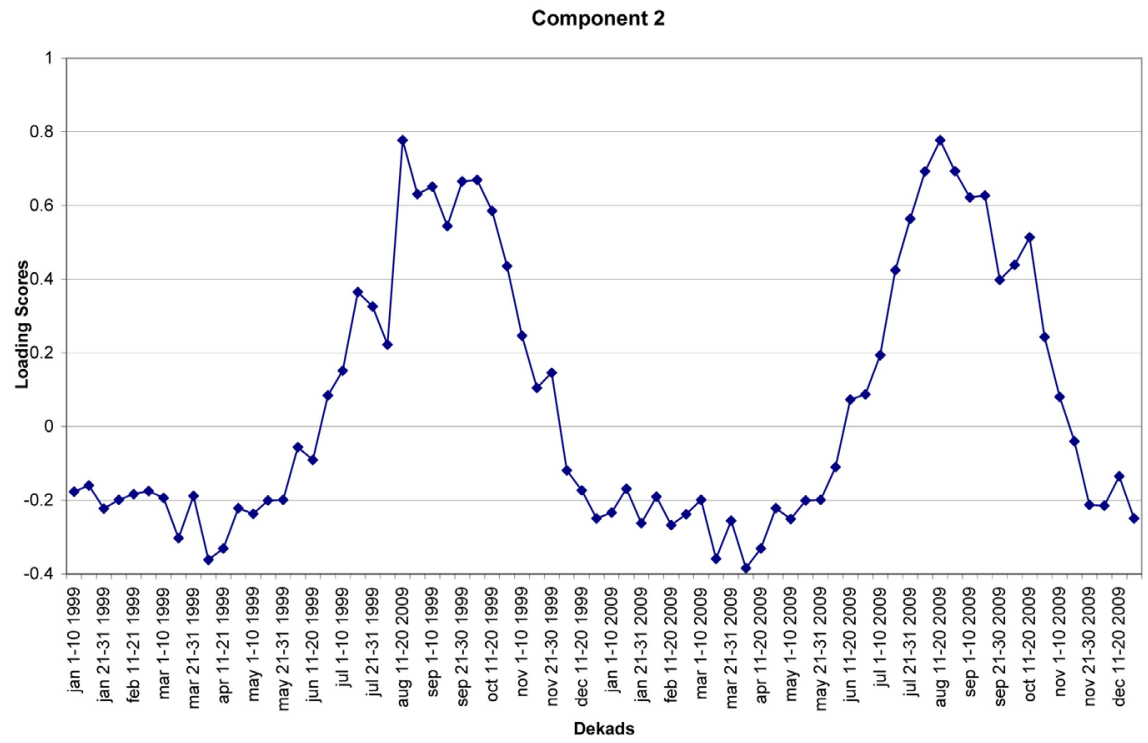

(b)

Figure 4. Component 2 image and its graph of loading scores (source: PCA analysis). (a) Component 2 image; (b) Graph of Component 2 loading scores.

of the major dams in the northern savanna zone such as Kainji and Shiroro in Niger, Goronyo in Sokoto, Tiga in Kano and part of Lake Chad were negatively affected in varying degrees.

\subsection{Component 2 and Its Loading Scores}

This component image and its graph of loading scores (Figure 5(a) \& Figure $5(b))$ is the first change component which differs from Component 1 image. It explains about $3 \%$ of the total variance of the total dataset utilised in the analysis. The corresponding graph of its loading scores shows a cyclic trend differentiating two distinct peaks representing the 1999 and 2009 ENSO years. The cyclic trend shows positive values and peaks mostly in the second dekad in August 1999 and 2009. This corresponds to the rainfall pattern during the ENSO periods 


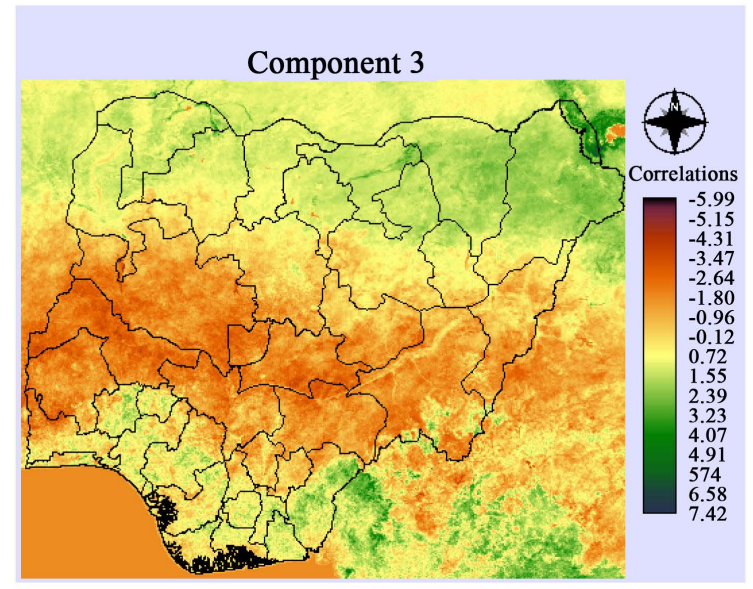

(a)

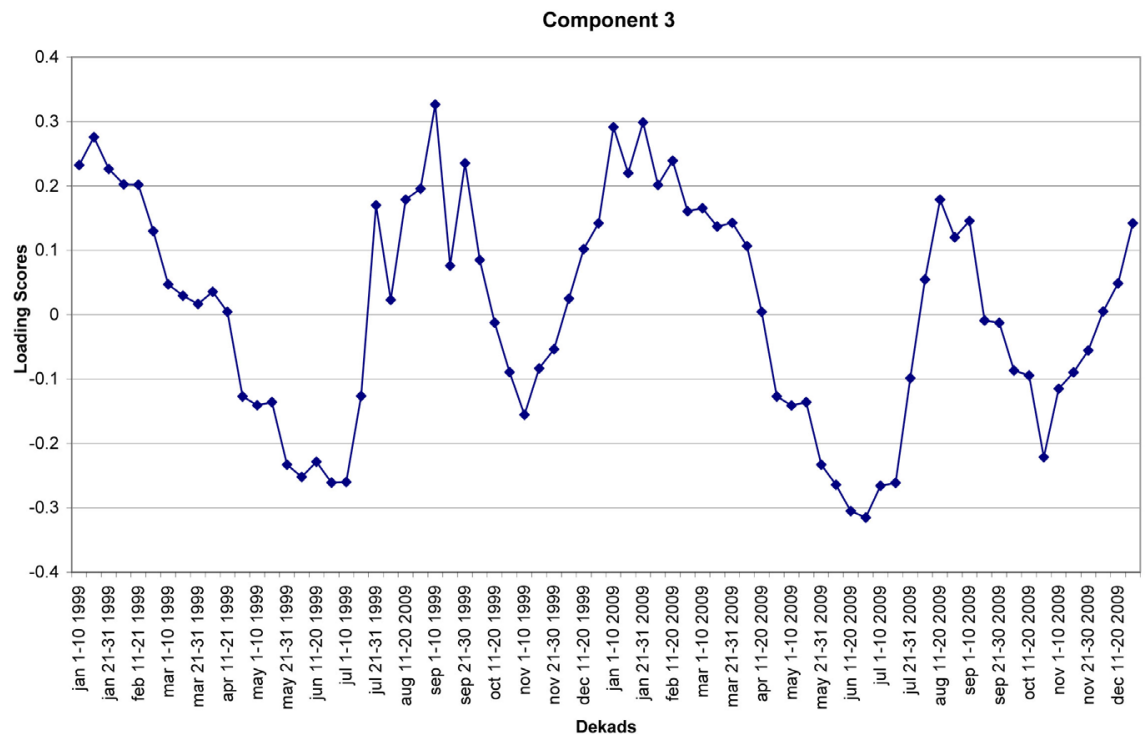

(b)

Figure 5. Component 3 image and its graph of loading scores (PCA analysis). (a) Component 3 image; (b) Graph of Component 3 loading scores.

of these years (Figure 2(a) \& Figure 2(b)) with lower peaks on the components loading graphs both in the first dekad of April 1999 and 2009 (Figure 4(b)). The positive peaks on the other hand are indicative of the peak rainy seasons across the country, although rainfall varies from north to south of the country due to the fluctuations of the Inter tropical Convergence Zone (ITCZ) [29]. The ITCZ reaches its northernmost position near the $19^{\text {th }}$ parallel in mid-August, when Sahel rainfall peaks, and after August, retreats rapidly southwards from June to September. This component image therefore, shows a clear pattern of the changes in vegetation because of the gradual movement of the encroaching Sahara desert into the 11 front line states of the northern part of the country to the fairly naturally vegetated surfaces in the southern part of the country [32]. Areas of negative vegetation anomaly pattern can be seen covering most of the southern states including the Niger Delta (indicating negative values on the compo- 
nent image) while the positive vegetation anomaly (in positive values on this component image) covers most of northwest and northeast ecological zones of the country. According to [33] the northern arid areas in Nigeria like in other arid and semi-arid areas of the world, is not just the total amount of rainfall that is important, but the timing and its distribution (as can be seen on Figure 2(a) \& Figure 2(b)). Accordingly, the pattern of rainfall particularly in the arid and semi-arid areas in the country is highly variable in spatial and temporal dimensions with an inter-annual variability of between 15 and 20 percent. Hence, the changes in the pattern of negative and positive vegetation anomaly across this component image corresponds to the rainfall pattern of the gauging stations in the frontline states prone to desertification (Figure $1(b)$ ) as well as the negative and positive anomalies where drought and floods were experienced during the 1999 and 2009 ENSO events in some states across the country.

\subsection{Component 3 and Its Loading Scores}

Component 3 image (Figure 5(a)) is the second change image exhibiting about $4 \%$ of the total variance in the $72 \mathrm{NDVI}$ dataset. Its graph of the loading scores looks similar to that of component 2 in its cyclic trend of vegetation dynamics. However, its peaks for the positive scores in 1999 fell in the second dekad of January and first dekad of September, while in 2009 the highest peak of the positive scores on the graph are in the last dekad of January and second dekad of August (Figure 5(b)). As for the negative scores, low peaks are located in the first dekad of July 1999 and last dekad of June 2009. Hence, this component image presents a positive anomaly pattern of the vegetation NDVI mostly within Sokoto, Kebbi, Kano, Jigawa, northern part of Bauchi, Yobe and Borno states, while the negative anomaly pattern can be seen in the central zone of the country located in Niger, Kwara, Oyo, Nasarawa, FCT, Kogi and Benue states.

\subsection{Component 4 and Its Loading Scores}

This is the third vegetation change component which shows about $2 \%$ of the total variance in the total time-series dataset (Table 1). Its graph of the loading scores indicated the highest peak located in the first dekads of August 1999 and 2009. However, while the graph of the 1999 La-Nina year is skewed to the left, that of the El-Nino of 2009 is skewed to the right. Both positive and negative anomaly patterns can be seen on this component image. For example, areas around Kainji dam and along rivers Niger and Benue look green. This can be linked to the 2009 floods which affected most of the major rivers and tributaries in the country in October that year. The resulting anomaly in the pattern of vegetation which appears green can be seen across the country. This indicated high positive values on the loading scores of this component. Thus, in most of the front-line states vegetation growth is limited by water such that the relative density of vegetation becomes a good indication of drought. Consequently, less rains were experienced during the La-Nina of 1999 particularly in Katsina and Yobe 
states (Figure 2(a)), and as the graph of loading scores on this component image indicates, particularly from the second dekad of August till the second dekad of October of 1999 (Figure 6(b)). On the other hand, the sandy soils in most of the arid and semi arid areas in the study area are usually low in organic matter, nitrogen and phosphorus also degrade rapidly under conditions of intensive rainfall [34]. Furthermore, based on the findings by [35] and, because of the nature of the rainfall in the front-line states which support mostly savanna vegetation the density of trees and other plants tend to be decreasing as one moves northwards. This is another reason why the savanna ecosystem of this zone in the country is very sensitive to human and animal population pressure. As [36] reported, there was a decline in rainfall amount in some of the southern parts of the country between 1995 to 2000, this could have explained further, the negative NDVI anomaly pattern in the southern part of the country on this component image.

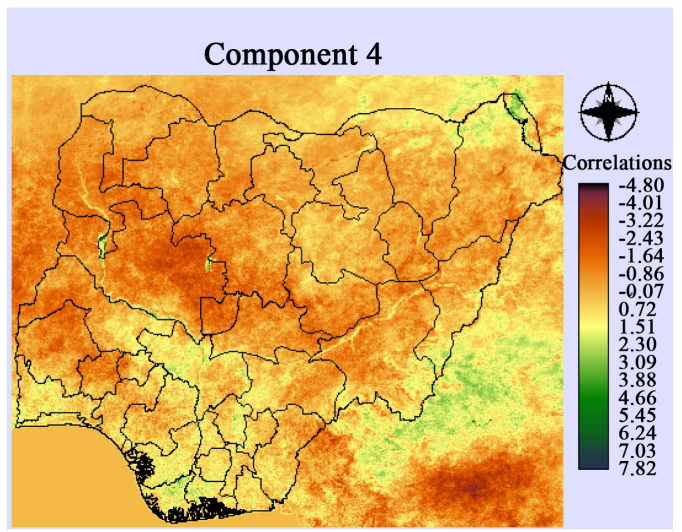

(a)

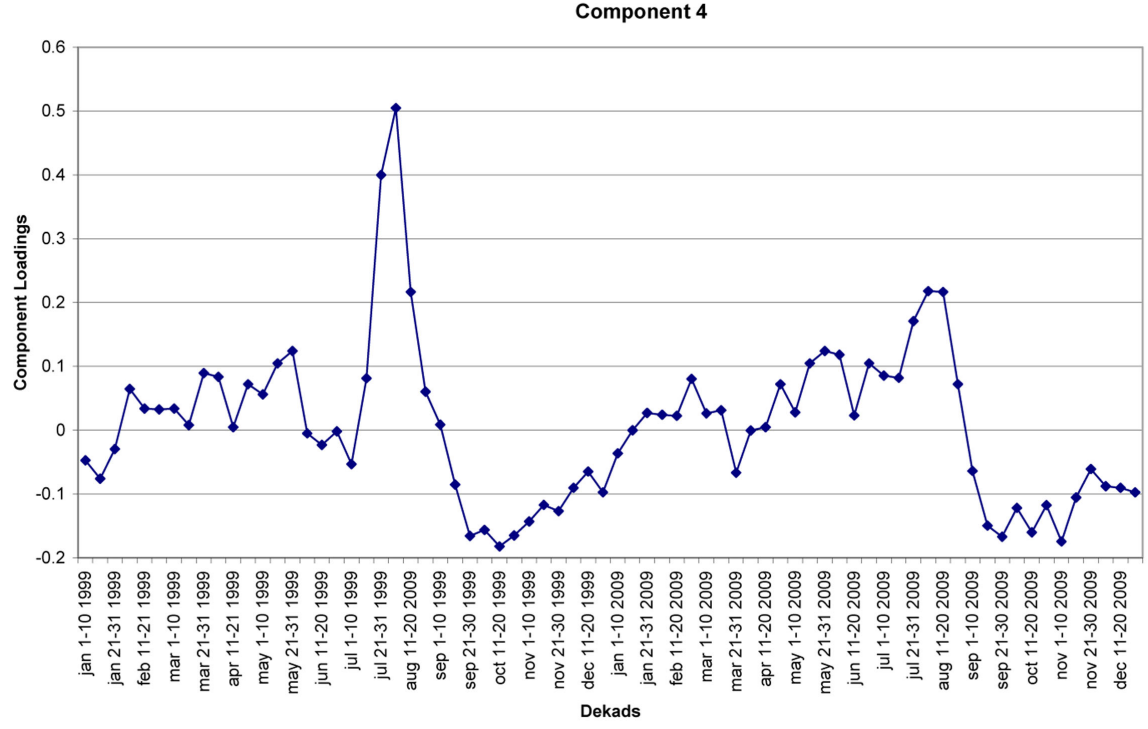

(b)

Figure 6. Component 4 image and its graph of loading scores (source: PCA analysis). (a) Component 4 image; (b) Graph of Component 4 loading scores. 


\subsection{Maps of Vegetation Status and Change Classes}

From the results, Component 1 images of 1999 and 2009 and subsequent image differencing and classification (Figure 7 and Figure 8) as well as the percentage change image (Figure 9) it is very clear that changes in both status and classes in vegetation canopy and vigor affected not only the front-line states but also the southern part of the country within the ten year period (1999 to 2009). For example, the low and very low vegetated areas combined fell in the frontline states considered as desertification zone areas. In summary, about $15 \%$ of the study area experienced one form of negative change in NDVI vegetation resource or another (including part of southern Niger and northern part of Cameroon). However, the naturally vegetated areas of the southern part and irrigated areas across the country had positive changes (Table 2). By implication, about 35\% of the study area (which includes few areas of adjoining countries) experienced one form of positive change or another in either vegetation canopy or vigor.

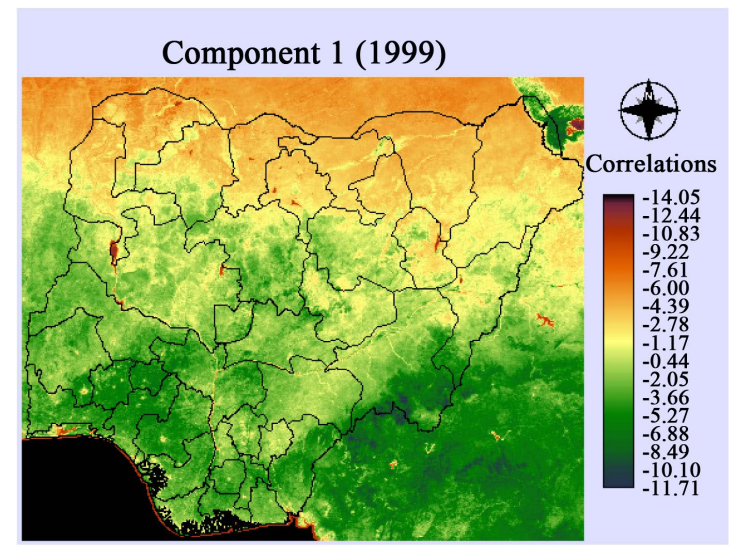

(a)

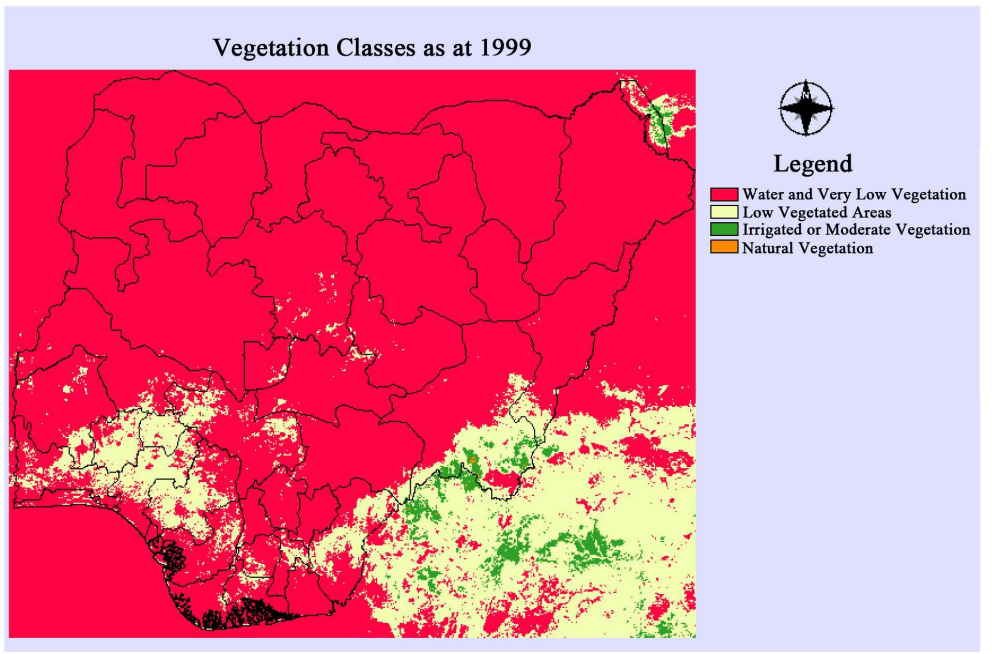

(b)

Figure 7. Comp. 1 images and vegetation classes for the 1999 La-Nina Year (source: image classification). (a) Component 1 image (1999); (b) Classified 1999 component1 image. 


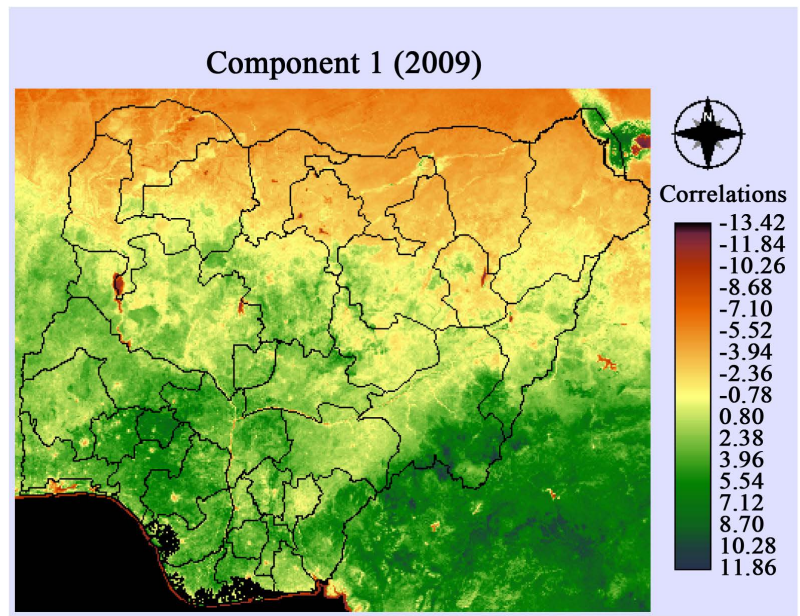

(a)

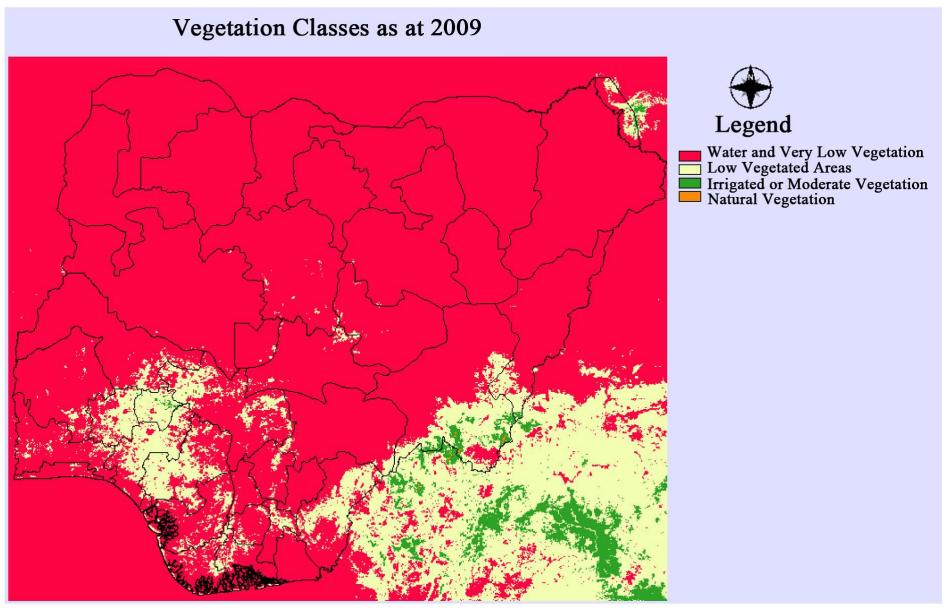

(b)

Figure 8. Comp. 1 image and vegetation classes for the 2009 El-Nino Year (source: image classification). (a) 2009 Component 1 image; (b) Classified 2009 Component 1 image.

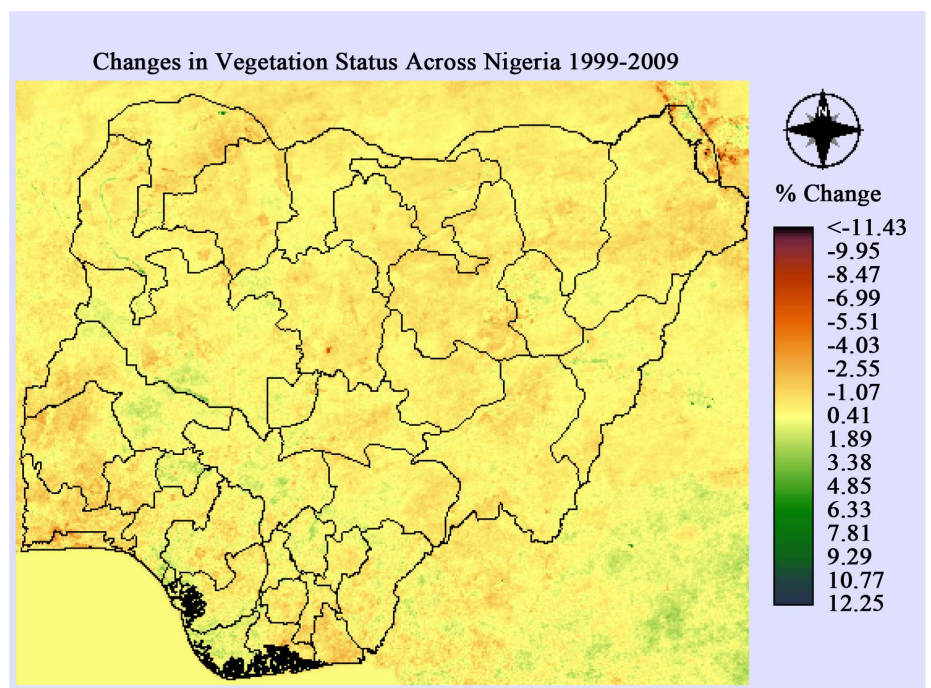

Figure 9. Change image from Components 1 images of 1999 and 2009 ENSO Years (source: percentage change analysis). 
Results in Figures 3-6, indicated varying correlations with the total dataset though the first component (PC1) which accounts for $69 \%$ of total variance in the dataset, correlates strongly across all years. Higher values are directly linked to the high density of vegetation in the study area while lower values correspond to places of arid areas and where the dominant vegetation is grass and shrubland.

\section{Conclusion}

From the results derived from this broad assessment, it can be concluded that dataset acquired from SPOT satellite for the purpose of monitoring the status of vegetation as a resource can be very useful for consistent and periodic monitoring of land cover generally. In particular, issues relating to climatic impacts globally, continentally, regionally, nationally and even at local levels can be undertaken. At the national level for example, a broad assessment using time-series of medium spatial resolution dataset can be undertaken. Once a systematic methodology is devised, adopted and maintained it can go along way for the policy makers particularly in monitoring vegetation as a resource. Areas of likely hazards such as drought and floods as well where serious disasters occurred can be analysed for sustainable environmental and resource management. Further research should include socio-economic data and extensive ground-truthing where area covering Nigeria should exclusively be analysed.

\section{Acknowledgements}

The researchers are grateful to the SPOT-Vegetation Programme for providing the SPOT-NDVI data utilised in this assessment of vegetation resource dynamics across Nigeria. The data was retrieved from www.spot-vegetation.com and the clipping of the AOI was through the VGTExtract Software also provided by VITO, Belgium. We are also grateful to NiMet in Nigeria for the monthly rainfall data.

\section{Conflicts of Interest}

The authors declare no conflicts of interest regarding the publication of this paper.

\section{References}

[1] Audu, I.A. and Adie, L.A. (2018) Desertification in Northern Nigeria: Causes and Consequences. The Environmental Studies, 1, 20-37.

[2] Emodi, E.E. (2013) Drought and Desertification as They Affect Nigerian Environment. Journal of Environmental Management Safety, 4, 45-54.

[3] Olagunju, I.E. (2015) Drought, Desertification and the Nigerian Environment: A Review. Journal of Ecology and Natural Environment, 7, 196-209. http://www.academicjournals.org/JENE

[4] Soussan, J.G. and Millington, A.C. (1992) Forest, Woodlands and Deforestation. In: Mannion, A.M. and Bowlby, S.R., Eds., Environmental Issues in the 1990s, John 
Wiley and Sons Ltd., Hoboken, 16-43.

[5] Rogers, D.J., Hay, S.I., Packer, M.J. and Wint, G.R.W. (1997) Mapping Land-Cover over Large Areas Using Multispectral Data Derived from the NOAA AVHRR: A Case Study of Nigeria. International Journal of Remote Sensing, 18, 3297-3303. https://doi.org/10.1080/014311697217107

[6] Tucker, C.J., Townshend, J.R.G. and Goff, T.E. (1985) African Land-Cover Classification Using Satellite Data. Science, 227, 369-375.

https://doi.org/10.1126/science.227.4685.369

[7] Justice, C.O., Townshend, J.R.G., Holben, B.N. and Tucker, C.J. (1985) Analysis of the Phenology of Global Vegetation Using Meteorological Satellite Data. International Journal of Remote Sensing, 6, 1271-1318.

https://doi.org/10.1080/01431168508948281

[8] Townshend, J.R.G., Justice, C.O. and Kalb, V.T. (1987) Characterization and Classification of South American Landcover Types Using Satellite Data. International Journal of Remote Sensing, 8, 1189-1207. https://doi.org/10.1080/01431168708954764

[9] Prince, S.D. and Justice, C.O. (1991) Coarse Resolution Remote Sensing of the Sahelian Environments. International Journal of Remote Sensing, 12, 1137-1146. https://doi.org/10.1080/01431169108929718

[10] Tucker, C.J., Newcomb, W.W., Los, S.O. and Prince, S.D. (1991) Mean and Inter Year Variation of Growing Season Normalised Difference Vegetation Index for the Sahel 1981-1989. International Journal of Remote Sensing, 12, 1133-1155. https://doi.org/10.1080/01431169108929717

[11] Millington, A.C., Wellens, J., Settle, J.J. and Saull, R.J. (1994) Explaining and Monitoring Land Cover Dynamic in Drylands Using Multi-Temporal Analysis of NOAA AVHRR Imagery. In: Foody, G. and Curran, P., Eds., Environmental Remote Sensing from Regional to Global Scales, John Wiley and Sons Ltd., Hoboken, 16-43.

[12] Yelwa, S.A. (2004) Mapping Potential Areas of Rift Valley Fever (RVF) Outbreaks in Livestock with Emphasis on Nigeria Using Time-Series Vegetation Index Data. Proceedings of the Society for Animal Production, Sokoto, 21-25 March 2004, 70-74.

[13] Yelwa, S.A. (2005) Landcover Changes across Nigeria as Detected from High Temporal Resolution Meteorological Data. Maiduguri Journal of Arts and Social Sciences, 3, 72-79.

[14] Yelwa, S.A. (2008) Broadscale Vegetation Change Assessment across Nigeria from Coarse Spatial and High Temporal Resolution AVHRR Data. Cuvillier Verlag, Göttingen Press, Göttingen, 350 p.

[15] Yelwa, S.A. and Noma, S.S. (2007) A Modelling Approach to the Study of Rainfall Impact on Vegetation Biomass Productivity over Nigeria Using Multi-Temporal Satellite Data. In: Musa, D.A. and Wokoma, F.O.A., Eds., Achieving Millennium Development Goals through Mapping, Nigerian Cartographic Association Special Publication, Dalim Publishers, Kaduna, 41-58.

[16] Eniolorunda, N.B., Abdulrahim, M.A. and Yelwa, S.A. (2008) Application of Remote Sensing to Vegetation Change Analysis in the Upper River Niger Valley, North-Western Nigeria. Maiduguri Journal of Arts and Social Sciences, 6, 40-49.

[17] Yelwa, S.A. and Isah, A.D. (2010) Analysis of Trends in Vegetation AVHRR NDVI Data across Sokoto State 1982-1986 Using Remote Sensing and GIS. Nigerian Journal of Basic and Applied Sciences, 18, 90-96.

https://doi.org/10.4314/njbas.v18i1.56849 
[18] Muazu, A., Yelwa, S.A. and Abbas, B. (2013) Mapping of Gully Susceptible Areas on in Agricultural Lands in Katsina State, Nigeria Using Remotely Sensed Data. Agricultural Journal, 8, 1-12.

[19] Adamu, I.A. (2007) Biodiversity Assessment in the Kwiambana Game Reserve, Zamfara State, Nigeria. Unpublished PhD Thesis, Department of Geography, Usmanu Danfodiyo University, Sokoto.

[20] Singh, A. and Harrison, A. (1985) Standardized Principal Components. International Journal of Remote Sensing, 6, 883-896. https://doi.org/10.1080/01431168508948511

[21] Eastman, J.R. and Fulk, M. (1993) Long Sequence Time Series Evaluation Using Standardised Principal Components. Photogrammetric Engineering and Remote Sensing, 59, 991-996.

[22] Anyamba, A., Tucker, C.J. and Eastman, J.R. (2001) NDVI Anomaly Patterns over Africa during the 1997/98 ENSO Warm Event. International Journal of Remote Sensing, 22, 1847-1859. https://doi.org/10.1080/01431160118270

[23] Richards, J.A. (1986) Remote Sensing Digital Image Analysis: An Introduction. Springer-Verlag, New York. https://doi.org/10.1007/978-3-662-02462-1

[24] Usman, U., Yelwa, S.A. and Gulumbe, S.U. (2012) An Assessment of Vegetation Cover Changes across Northern Nigeria Using Trend Line and Principal Component Analysis. Journal of Agriculture and Environmental Sciences, 1, 1-18.

[25] United Nations (2018) United Nations Convention to Combat Desertification: Great Green Wall. http://www.unccd.int/actions/great-green-wall-initiative

[26] UNCED (1997) Report on the Implementation of Agenda 21: Review and Progress for Nigeria. United Nations Commission on Sustainable Development, 5 th Session, New York, 7-25 April 1997.

https://www.un.org/esa/agenda21/natlinfo/countr/nigeria/natur.htm\#forests

[27] White, F. (1983) The Vegetation of Africa (Natural Resources Research Series, 20). UNESCO, Paris.

[28] Ilesanmi, O.O. (1971) An Empirical Formulation of an ITD Rainfall Model for the Tropics: A Case Study of Nigeria. Journal of Applied Meteorology, 10, 882-891. https://doi.org/10.1175/1520-0450(1971)010<0882:AEFOAI >2.0.CO;2

[29] Oguntoyinbo, J.S. (1982) Climate 2: Precipitation. In: Barbour, K.M., Oguntoyinbo, J.S., Onyemelukwe, J.O.C. and Nwafor, J.C., Eds., Nigeria in Maps, Hodder and Stoughton Ltd., London, 16-17.

[30] Areaola, O. (1982) Nigeria: Soils. In: Barbour, K.M., Oguntoyinbo, J.S., Onyemelukwe, J.O.C. and Nwafor, J.C., Eds., Nigeria in Maps, Hodder and Stoughton Ltd., London, 22-23.

[31] Lillesand, T.M. and Kiefer, R.W. (2005) Remote Sensing and Image Interpretation. Fifth Edition, John Wiley and Son, Inc., Hoboken.

[32] Yelwa, S.A. and Usman, U. (2017) Integration of Spatial Prediction in the Assessment of Vegetation Productivity in the Northern Part of Nigeria. American Journal of Climate Change, 6, 360-373. https://doi.org/10.4236/ajcc.2017.62018

[33] Mortimore, M. and Adams, W.M. (1999) Working the Sahel. Environment and Society in Northern Nigeria. Routledge, London, 226 p.

[34] Mortimore, M.J., Harris, F.M.A. and Adams, W.M. (2000) The Relevance of Nigerian Farmers' Responses to Dryland Farming Systems in India and Southern Africa. Department for International Development Renewable Natural Resources Research strategy, Semi-Arid Production System, Project R7093. 
[35] Mustapha, S.B., Undiandeye, U.C. and Gwary, M.M. (2012) The Role of Extension in Agricultural Adaptation to Climate Change in the Sahelian Zone of Nigeria. Journal of Environment and Earth Science, 2, 4858.

[36] Ezemonye, M.N. and Emeribe, C.N. (2011) Correlogram Analysis of Trends and Cycles in Rainfall over Southeastern Nigeria. Pakistan Journal of Social Sciences, 8, 325-333.

\section{List of Abbreviations}

AVHRR: Advanced Very High Resolution Radiometer

BELSPO: Belgium Development Agency

EMS: Electromagnetic Spectrum

ENSO: El-Nino Southern Oscilliations

ESA: European Space Agency

GIS: Geographical Information Systems

ITCZ: International Tropical Convergence Zone

NASA: National Aeronautics Space Administration

NDVI: Normalised Difference Vegetation Index

NIR: Near Infrared

NiMeT: Nigerian Meteorological Agency

NOAA: National Oceanic Atmospheric Administration

PCA: Principal Component Analysis

SPC: Standardised Principal Components

SPOT: Satellite Pour L'Observation de la Terra

UN: United Nations

VIS: Visible Infrared Spectrum 